\title{
Perception and Motivation to Quit Smoking Based on Teenager's Smoking Behaviour
}

\author{
Aoliyah Pitria Piddin1,*, Laili Rahayuwati², and Eka Afrima Sari3 \\ 1Student of Faculty of Nursing Universitas Padjadjaran, Bandung, Indonesia; \\ aoliyah15001@mail.unpad.ac.id \\ 2Departement of Community Nursing, Faculty of Nursing Universitas Padjadjaran, Bandung, Indonesia; \\ ailirahayuwati@unpad.ac.id \\ ${ }^{3}$ Department of Medical Surgery Nursing, Faculty of Nursing Universitas Padjadjaran, Bandung, Indonesia; \\ ekaafrimasari@gmail.com \\ *Correspondence: aoliyah15001@mail.unpad.ac.id
}

Type of the Paper (Article)

Received: July 26, 2020; Accepted: August 2, 2020; Published: September 3, 2020

https://doi.org/10.29253/achnr.2020.22042

\begin{abstract}
Smoking behaviour has a harmful impact on teenagers, including the lack of motivation to achieve academically. Previous research claims that the perception of smoking and the motivation to quit smoking may impact smoking behaviour. The purpose of the research is to identify which one of both variables play a stronger role in its impact toward the teenager's smoking behavior. The research is a quantitative research involving 192 teenagers as the sample in Bandung city, using questionnaires on perception, motivation, and behavior. Data analysis used univariate and bivariate and Spearman correlation tests. The findings of this research shows that $56 \%$ of Bandung teenagers have a positive perception, $51 \%$ others a positive motivation, and $56 \%$ positive behaviour. This proves that the coefficient value of the correlation between perception and motivation is 0.238 , and the coefficient value of the correlation between motivation and behavior is 0.387 . This research concludes that the motivation to quit smoking has a stronger relationship than the perception of smoking. Thus, to change the smoking behaviour in teenagers, it is necessary to increase the motivation to quit smoking whatsoever. Possible actions is to have a counselling session to help change the teenager's health behaviour. The value of study to obtain the unique characteristic of teenager in Indonesia.
\end{abstract}

Keywords: motivation to quit smoking; smoking behavior; smoking perception

\section{Introduction}

Adolescence is a transitional period from childhood to adulthood; at this stage, some emotional and behavioral turbulence are identified, one of which is smoking problems (Childs, 2014). Based on the research from Azagba and Wolfson (2018) the quantity and frequency of smoking can be considered high and categorized as heavy smokers, including electronic smokers.

The data from World Health Organization (WHO) (2018) claim that the number of smokers above 15 years old in 2015 is 1.114 million, consisting of 939 million male and 175 million other females. In Asia, there are 237 million smokers, slightly higher than the number in the last 5 years, which is 235 million in 2010. Out of all Asian countries, Indonesia has the second highest number of smokers after India. According to WHO (2018), Indonesia has 74 million smokers in 2016 (71.637 million male and 
2.456 million female). According to Basic Health Research (Riskesdas, 2013) in Riau, smokers above 10 years old in Riau Province are $27.2 \%$ out of the whole population. On the other hand, West Java has $27.1 \%$ smokers out of its whole population.

As the capital city of West Java, Bandung has a particularly high number of smokers. According to an article from Tobacco Control Support Center Indonesia (2011), there are 10.9 million smokers with $30 \%$ of its population. This number comprises heavy smokers who spend as many as 12 to 29 cigarettes per day. From Riskesdas (2013), based on the characteristics, active smokers are mostly found on male (64.9\%) and females (2.1\%). Education-wise, most smokers are high school graduates. Based on age, $20.9 \%$ of all smokers in West Java is 16 to 19 years old, which is categorized as a middle adolescent.

The regulation of health ministry number 28 year 2013 regulated the statement of health warning and information on the package of cigarette products. This regulation leads to the decrease of the number of smokers above 15 years old, from $36.3 \%$ in 2013 to $32.8 \%$ in 2016. However, this decrease does not last until next year because according to the Central Statistics Agency of the Ministry of Health Indonesia, 2018, the number of smokers rose back to $33.8 \%$ in 2018.

The health program due to chemicals in cigarettes due to growth and development of teenagers, one of which is brain development, so that it will impact the decrease of academic functions in school age (Liem, 2016) (Tulenan, Rompas \& Ismanto, 2015).

Smoking behavior in teenagers is impacted by various factors including susceptibility, poor decision-making skill, and poor emotional management. Therefore, they choose to keep smoking due to the ignorance of the cause and focus more on pseudo excitement (Casey, 2010). Moreover, Virgili and Severson (1991) claim that teenagers often perceive that the benefit of smoking is doing more good than harm. Apart from susceptibility and poor decision-making skill, one of the reasons teenagers smoke is because of their friends; they want to feel what it is like to smoke because their friends encourage them to do so (Mirnawati, Nurfitriani, Zulfiarini and Cahyati, 2017). This argument is supported by Wang et al., (1995) on their research involving 6900 male teenagers aged 14-18 years old, claiming that peers have a huge impact on their intention to smoke. They also think that smoking symbolizes power, prosperity, and maturity.

Noviana, Riyanti, and Widagdo, (2016) as much as 35.8\% teenagers feel at ease after smoking, $26.3 \%$ satisfied, $19.3 \%$ content. Other factors that can impact smoking behaviour include family, actively smoking parents, and lack of communication in the family (Hill et al., 2005).

Brener et al., (2003) claim that risky behaviours on smoking teenagers can be impacted by cognitive and situational factors. Based on the Taxonomy Bloom hierarchy, the cognitive domain has several levels, one of them being knowledge. However, it contrasts with the research result from Noviana, et al., (2016) claiming that knowledge has nothing to do with types of teenager's behaviour. Other variables beside knowledge in the cognitive domain is perception. This is supported by Health Belief model theory that one's behaviour can be impacted by perception, several of which include perceived susceptibility, perceived seriousness, perceived benefits, perceived barriers, and perceived threat (Rosenstock, 1974 in Morris, Marzano, Dandy and O'Brien, 2012). While Binita et al., (2016) claimed that perceived seriousness, susceptibility, and barriers have a significant impact on the types of smoking behaviour, the perception of smoking benefits do not. Afif and Astuti (2015) said that perception has a significantly positive relationship with smoking behaviour on teenagers. Meanwhile, Rahayuningsih (2015) said that perceived susceptibility, seriousness, and barriers have nothing to do with smoking behaviour, while the perception of smoking benefits do.

Another factor affecting the smoking behaviour on teenagers is motivation. One would smoke when they have the motivation, and vice versa. If they have the motivation to quit, then the chance of them quitting smoking will be higher compared to those who do not have any motivation at all.

Smoking behavior on teenagers can be divided in two types: Positive behavior toward health and negative behavior toward health. The difference is impacted by several factors such as the perception of smoking and motivation to quit. To understand the factors that have a stronger relationship toward smoking behaviour, it is necessary to compare some factors relating to it and analyze both to find out which ones have a stronger relationship.

Therefore, it is important to conduct research on the perception of smoking and the motivation to quit smoking toward smoking behavior. Therefore, the general aim of this research is to analyze the 
relationship between the perception of smoking and the motivation to quit toward smoking behavior in teenagers.

\section{Literature Review}

Savvides, Christophi, Paisi, Pampaka, Kinnunen, and Connolly's (2014) study on factors related to youth smokers' desire. This study utilized a cluster sample design for school students the 2005-2006 academic year, and data analysis using logistic regression. The results showed as many as 1,591 students currently smokers (14\%) and $734(46.1 \%)$ of those who wanted to quit smoking. Both men and women are strong predictors of intention to stop smoking. The intention to stop smoking is associated with the belief that smoking is harmful. Also, there is inversely proportional to having a peer who smokes, in boys, and the belief that smoking is harmful to others. Further, the considers smokers as less attractive, and inversely proportional to pocket money, in girls.

A responden's perception of the dangers of smoking can make a person stop smoking. This is also supported by the research of Prasetyo and Indrawati (2016) in Magelang, Indonesia about the relationship between perceptions of the dangers of smoking with the intention to stop smoking in members of the regional Inter-Club Indonesia community. The sample of this study was 45 smokers who are members of the Magelang regional Inter-Club Indonesia community. The sampling technique uses convenience sampling and data collection uses a scale of perception of the dangers of smoking (35 valid items, $\alpha=0.95$ ) and the intention to quit smoking scale ( 44 valid items, $\alpha=0.97$ ). The results showed that the results of a simple regression analysis showed a correlation coefficient of $\mathrm{rxy}=0.72$ with $\mathrm{p}<0.01$. This shows a significant positive relationship between perceptions of the dangers of smoking with the intention to stop smoking in the members. That is, the more positive perception of the dangers of smoking, the higher the intention to stop smoking, and vice versa. Perception of the dangers of smoking made an effective contribution of $52.4 \%$ in the intention to stop smoking.

\section{Methodology}

The research was designed quantitative. From the problem statement, the method in this research was correlational research. The variables in this research included perception of smoking, motivation to quit smoking, and smoking behavior.

Sampling was done using simple random techniques on teenagers in Bandung. If there was any chosen sample but did not fulfill the inclusion criteria (not smoking) or if one was not present during the day of the research, researchers chose the next sample as their substitute.

Data processing in this research was done using a computer software. The degree of perception, motivation, and respondent's behavior was categorized further to calculate the frequency distribution of each degree. The research used the Spearman correlation test because the scale of both variables is ordinal. This means that if the test result shows significance value $<0.05$, then there is no significant correlation between the variable of perception of smoking and motivation to quit (Santoso, 2008).

\section{Result}

The respondent's characteristics in this research include age, grade, gender, monthly allowance, any family member smoking, smoking period, and the reason for starting smoking.

Table 1. The respondent's frequency distribution based on socio-demographic characteristics. $(n=192)$

\begin{tabular}{lcc}
\hline Characteristics & $\begin{array}{c}\text { Frequency } \\
\text { (f) }\end{array}$ & $\begin{array}{c}\text { Percentage } \\
\text { (\%) }\end{array}$ \\
\hline Age & & \\
15 years old & 24 & 12.5 \\
16 years old & 82 & 42.7 \\
17 years old & 82 & 42.7 \\
18 years old & 4 & 2.1 \\
Grade & & \\
$\quad$ First year & 91 & 47.4 \\
$\quad$ Sophomore year & 101 & 52.6 \\
\hline
\end{tabular}




\begin{tabular}{lrr}
\hline & Table 1 Continued & \\
\hline Gender & & \\
$\quad$ Male & 192 & 100 \\
$\quad$ Female & 0 & 0 \\
Allowance (/month) & 122 & 63.5 \\
$\quad$ Rp 500.000 & 56 & 29.2 \\
$\quad$ Rp 500.000-1000.000 & 14 & 7.3 \\
$\quad$ Rp 1000.000 & 29 & 15.1 \\
Smoking Family Members & 163 & 84.9 \\
$\quad$ No & 73 & 38.0 \\
$\quad$ Yes & 43 & 22.4 \\
Smoking Period & 76 & 39.6 \\
$\quad<1$ year & 120 & 62.5 \\
$\quad$ 1-2 years & 57 & 29.7 \\
$\quad$ 2 years & 15 & 7.8 \\
$\quad$ Curious & & \\
$\quad$ Encouraged by Friends & & \\
$\quad$ See a Family Member Smoke & &
\end{tabular}

Table 2 is the result of the respondent's description on the perception of smoking, motivation to quit, and smoking behavior.

Table 2. The respondent's frequency distribution based on the degree of perception, motivation, and smoking behavior $(\mathrm{n}=192)$.

\begin{tabular}{lcc}
\hline Characteristics & $\begin{array}{c}\text { Frequency } \\
\text { (f) }\end{array}$ & $\begin{array}{c}\text { Percentage } \\
\text { (\%) }\end{array}$ \\
\hline Smoking Perception & & \\
$\quad$ Negative & 84 & 43.8 \\
$\quad$ Positive & 108 & 56.3 \\
Motivation to Quit Smoking & & \\
$\quad$ Negative & 94 & 49.0 \\
$\quad$ Positive & 98 & 51.0 \\
Smoking Behavior & & \\
$\quad$ Negative & 84 & 43.8 \\
$\quad$ Positive & 108 & 56.3 \\
\hline
\end{tabular}

Table 3 is the result on the degree of perception of smoking toward smoking behavior.

Table 3. The respondent's frequency distribution based on the degree of perception of smoking toward smoking behavior $(n=192)$.

\begin{tabular}{lccc}
\hline & \multicolumn{3}{c}{ Smoking Behavior } \\
\cline { 2 - 4 } Perception & $\begin{array}{c}\text { Negative } \\
\text { f }\end{array}$ & $\begin{array}{c}\text { Positive } \\
\text { f }\end{array}$ & $\begin{array}{c}\text { Total } \\
\text { f }\end{array}$ \\
\hline Negative & 48 & 36 & 84 \\
Positive & 36 & 72 & 108 \\
Total & 84 & 108 & 192 \\
\hline
\end{tabular}

The result of statistical test using the Correlation Spearman nonparametric test shows that the significance value or Sig. (2-tailed) is 0.0001 because Sig. (2-tailed) 0.001 is smaller than 0.005 . Therefore, there is a significant relationship between the perception of smoking and smoking behavior. Further, the coefficient correlation value between the perception of smoking and smoking behavior is 0.238 . Seen from the coefficient correlation value above, the value lies within the range of $0.00-0.25$, meaning the relationship between smoking perception and smoking behavior is weak.

Table 4 describes the degree of motivation to quit smoking toward smoking behavior. 
Table 4. The respondent's frequency distribution based on the degree of motivation to quit smoking toward smoking behavior $(\mathrm{n}=192)$.

\begin{tabular}{cccc}
\hline \multirow{2}{*}{$\begin{array}{c}\text { Motivation to } \\
\text { Quit Smoking }\end{array}$} & \multicolumn{3}{c}{ Smoking Behavior } \\
\cline { 2 - 4 } & Negative & Positive & Total \\
\hline Negative & 51 & 43 & 94 \\
Positive & 33 & 65 & 98 \\
Total & 84 & 108 & 192 \\
\hline
\end{tabular}

The result of Correlation Spearman nonparametric test shows that the significance value or Sig. (2tailed) is 0.0001 because Sig. (2-tailed) 0.001 is smaller than 0.005 . Therefore, there is a significant relationship between the motivation to quit smoking and smoking behavior. Further, the coefficient correlation value between the perception of smoking and smoking behavior is 0.387. Seen from coefficient correlation value above, the value lies within the range of $0.26-0.50$, meaning the relationship between smoking perception and smoking behavior is mediocre.

\section{Discussion}

This research shows that the perception of smoking has a weak relationship with smoking behavior. This is in line with Rahayuningsih (2015) to 104 students in one of vocational high schools (SMK) in Semarang, saying that the perception doesn't have any link to smoking behavior. This perception includes perceived susceptibility, perceived seriousness, and perceived barriers. From the research of Afif and Astuti (2015) involving 50 teenagers aged 15-18 years old in one of vocation schools say that there is a significantly positive relationship between the perception and smoking behavior. The determinant coefficient value is 0.392 , meaning that the perception variable contributes to the smoking behavior as much as $39.2 \%$. This means that although the perception of smoking has a link to smoking behavior, the perception does not fully impact the behavior.

This is because one's perception is impacted by various factors. According to Pieter and Saragih (2011) it can be impacted by willing, interest, and habit. The higher one's willingness on an object, the higher is his willingness to perceive it. The more he feels that the object is important, the more sensitive he is to the object. This also applies to habit. The more often one feels the object, the stronger his perception toward that object.

Another factor that may impact the behavior of smoking in teenagers is gender and age (Wijayanti, Dewi \& Rifqatussa'adah, 2017). Moreover, according to Hill et al., (2005) in their 11-year research involving 808 children aged 10 to 11 years old, claim that the status of smoking parents has contributed to creating the habit of smoking in teenagers. This research also says that parents need to reduce the conflict within the family, knowing that the bond between parents and children can also impact the smoking behavior. That is why if parents have a good relationship with their children, the chance of their children going to smoke will be lessened.

Wang et al., (1995) claim that smoking behavior is impacted by friends. With 6900 teenagers aged 14 to 18 years old, it proves that there are 2 to 4 close friends who smoke, especially if the friends are of same sex.

Besides, the internal factor of the teenager can impact both the impact and the perception. Virgili and Severson (1991) claim that the teenager's smoking behavior is dependent on the teenager themselves, especially on how they perceive the risk of smoking to themselves as individuals.

Although not directly related, this can impact the smoking behavior from the smoking style, intensity, and frequency. Therefore, this will determine whether their smoking behavior can lead to positive habits or negative, seen from the health perspective.

According to the Planned Behavior \& Reasoned Action theory, one's motivation can impact their behavior. In this research, the motivation to quit smoking also has an impact on their smoking behavior.

Motivation has an impact on smoking behavior which slowly turns to be healthy-positive. This is also supported by Kearney and O'Sullivan (2003, in Tombor et al., 2015). This research also shows that the strength of motivation has an impact that leads to health, therefore this motivation is important to 
change one's health behavior. To improve the motivation, one of the solutions is to provide counselling for teenagers. Saputra and Sary (2012) assert that changing a teenager's behavior through a transtheoretical model counselling is one of the most effective forms of intervention.

Based on the result of this research, it is important to increase the motivation to quit smoking done constantly for teenagers. Hopefully, this motivation will help to slow down the process of quitting. One of the ways to increase the motivation is through counselling face-to-face or peer counselling. Besides, the increase of this motivation also requires support from parents, friends, and surrounding people.

During the data collecting process, the respondents are in the process of learning in school, limiting the researcher to have enough time to proceed. Therefore, the researcher has limitations in explaining the content of questionnaires.

\section{Conclusion}

To conclude, increasing the perception and motivation to quit smoking is one of the ways to change the teenager's smoking behavior so that it could be healthy-positive. Another way is to get support from family, friends, and surrounding people. Motivational counselling is one way to increase the motivation and change health behavior to teenagers. This counselling can be done individually or groups and within the vicinity of the school.

\section{Acknowledgement}

We wish to acknowledge former Rector of Universitas Padjadjaran, Prof. Ganjar Kurnia, PhD, and Rector Universitas Padjadjaran, Prof. Dr. Tri Hanggono Achmad, and Dean Faculty of Nursing Universitas Padjadjaran Kusman Ibrahim, SKp, MNS, PhD for great support to this study.

\section{References}

Afif, A. N., \& Astuti, K. (2015). Hubungan Antara Persepsi Terhadap Iklan Rokok dengan Perilaku Merokok Pada remaja, 17(1).

Agustina, F. (2017). Hubungan Umur dan Prilaku Merokok Siswa Kelas I smp terhadap Prestasi Belajar. Cendekia Medika, 2(2), 106-116.

Azagba, S., \& Wolfson, M. (2018). E-cigarette Use and Quantity of Cigarette Smoking among Adolescent Cigarette smokers: A Finite Mixture Model Analysis. Drug and Alcohol Dependence, 185(December 2017), 33-39. https://doi.org/10.1016/j.drugalcdep.2017.12.003

Badan Pusat Statistik (BPS) Kementerian Kesehatan Indonesia. (2018). Persentase Merokok Pada Penduduk Umur $\geq \quad 15$ Tahun Menurut Provinsi, 2015-2018. Retrieved from https://www.bps.go.id/dynamictable/2018/07/02 15:24:37.29374/1514/persentase-merokok-padapenduduk-umur-15-tahun-menurut-provinsi-2015-2016.html

Binita, A. M., Istiarti, V. T., \& Widagdo, L. (2016). Hubungan Persepsi Merokok dengan Tipe Perilaku Merokok pada Siswa SMK "X" di Kota Semarang. Jurnal Kesehatan Masyarakat (E-Journal)), 4, 268-276.

Brener, N. D., Ph, D., Billy, J. O. G., Ph, D., \& Grady, W. R. (2003). Assessment of Factors Affecting the Validity of SelfReported Health-Risk Behavior Among Adolescents: Evidence From the Scientific Literature, 436-457. https://doi.org/10.1016/S1054-139X(03)00052-1

Casey, B. J. (2010). Neurobiology of the Adolescent Brain and Behavior : Implications for Substance Use Disorders. Journal of The American Academy of Child and Adolescent Psychiatry, 49(12), 1189-1201. https://doi.org/10.1016/j.jaac.2010.08.017

Childs, K. K. (2014). Exploring Gender Differences in Constellations of Problem Behaviors and Associated HealthRelated Factors during Adolescence. Criminal Justice Studies, 27(1), 20-42. https://doi.org/10.1080/1478601X.2013.873203

Harakeh, Z., Scholte, R. H. J., Ph, D., Vermulst, A. A., Ph, D., Vries, H. De, ... Ph, D. (2004). Parental factors and adolescents' smoking behavior: an extension of The theory of planned behavior, 39, 951-961. https://doi.org/10.1016/j.ypmed.2004.03.036

Hill, K. G., Ph, D., Hawkins, J. D., Ph, D., Catalano, R. F., Ph, D., ... Ph, D. (2005). Family influences on the risk of daily smoking initiation, 37, 202-210. https://doi.org/10.1016/j.jadohealth.2004.08.014

Kementerian Kesehatan Republik Indonesia. (2013). Peraturan Menteri Kesehatan Republik Indonesia No. 28 Tahun 2013 tentang Pencantuman Peringatan Kesehatan dan Informasi Kesehatan pada Kemasan Produk Tembakau.

Liem, A. (2014). Pengaruh Media Massa, Keluarga, dan Teman terhadap Perilaku Merokok Remaja di Yogyakarta, (May). https://doi.org/10.7454/mssh.v18i1.3460 
Liem, A. (2016). Pengaruh Nikotin Terhadap Aktivitas dan Fungsi Otak Serta Hubungannya dengan Gangguan Psikologis pada Pecandu Rokok. Buletin Psikologi, (January 2010).

Mirnawati, Nurfitriani, Zulfiarini, F. M., \& Cahyati, W. H. (2017). Perilaku Merokok pada Remaja Umur 13-14 Tahun Mirnawati1. Higeia Journal of Public Health Research and Development, 1(4), 109-119. https://doi.org/10.15294 /higeia/v2i3/26761

Morris, J., Marzano, M., Dandy, N., \& O’Brien, L. (2012). Theories : Behaviour Change, 1-27.

Noviana, A., Riyanti, E., \& Widagdo, L. (2016). Determinan Faktor Remaja Merokok Studi Kasus di SMPN 27 Semarang. Jurnal Kesehatan Masyarakat (E-Journal), 4(3), 960-969.

Pieter, J., \& Saragih. (2011). Pengantar Psikopatologi untuk Keperawatan. Jakarta: Kencana.

Prasetyo, D. Y., \& Indrawati, E. S. (2016). Hubungan Antara Persepsi Terhadap Bahaya Rokok Dengan Intensi Berhenti Merokok pada Anggota Komunitas Inter Club Indonesia Regional Magelang. Jurnal Empati, 5(3), 453-457.

Rahayuningsih, F. (2015). Hubungan Antara Persepsi Perilaku Merokok Dengan Perilaku Merokok Siswa SMK X Di Kota Semarang, 3(April), 220-229.

Riskesdas. (2013). Riset Kesehatan Dasar 2013. Proceedings, Annual Meeting - Air Pollution Control Association, 6. https://doi.org/1 Desember 2013

Rosenstock, I. M. (1974). Historical Origins of The Health Belief Model. Health Education Monographs, 2(4), 328-335.

Santoso, E. B. (2008). Faktor-Faktor Lingkungan yang Mempengaruhi Perilaku Merokok Remaja di Desa Godegan Tamantirto Kasihan Bantul. (Thesis). Universitas Muhammadiyah Yogyakarta.

Saputra, A. M., \& Sary, N. M. (2012). Konseling Model Transteoritik dalam Perubahan Perilaku Merokok pada Remaja Counseling with the Transtheoritical Model in Changing Smoking Behavioral among Adolescents, (534).

Savvides, E. C. G., Christophi, C. A., Paisi, M., Pampaka, D., Kinnunen, T., \& Connolly, G. N. (2014). Factors Associated with Intent to Quit Tobacco Use in Cyprus Adolescents. Preventive Medicine, 60, 83-87. https://doi.org/10.1016/j.ypmed.2013.12.016

Tobacco Control Support Center Indonesia [TCSC]. (2011). 30 Persen Warga Bandung Perokok. Retrieved from http://www.tcsc-indonesia.org/30-persen-warga-bandung-perokok/

Tombor, I., Shahab, L., Neale, J., Michie, S., \& West, R. (2015). Smoker Identity and Its Potential Role in Young Adults ' Smoking Behavior : A Meta-Ethnography, 34(10), 992-1003.

Tulenan, M., Rompas, S., \& Ismanto, A. . (2015). Hubungan perilaku merokok dengan prestasi belajar pada remaja perokok di SMA Negeri 1 Remboken. Ejournal Keperawatan (e-Kp), 3(2).

Virgili, M., \& Severson, H. H. (1991). Adolescents ' Smoking Behavior and Risk Perceptions. Journal of Substance Abuse, 3(3), 315-324. https://doi.org/10.1016/S0899-3289(10)80015-X

Wang, M. Q., Fitzhugh, E. C., Westerfield, C., \& Eddy, J. M. (1995). Family and Peer Influences on Smoking Behavior Among American Adolescents : An Age Trend, (94), 200-203.

WHO. (2018). WHO Global Report on Trends in Prevalence of Tobacco Smoking 2000-2025, Second Edition, 121.

Wijayanti, E., Dewi, C., \& Rifqatussa'adah. (2017). Faktor-faktor yang Berhubungan dengan Perilaku Merokok pada Remaja Kampung Bojong rawalele, Jatimakmur, Bekasi. Global Medical and Health Communication (GMHC), 5(3), 194-198. https://doi.org/10.29313/gmhc.v5i3.2298 